Article

\title{
Climate Change and Intense Irrigation Growth in Western Bahia, Brazil: The Urgent Need for Hydroclimatic Monitoring
}

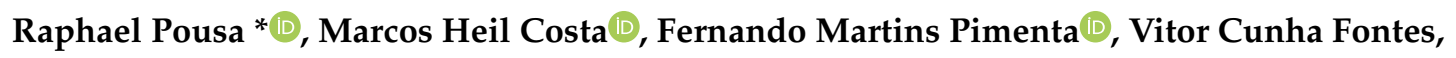 \\ Vinícius Fonseca Anício de Brito and Marina Castro \\ Department of Agricultural Engineering, The Federal University of Viçosa, Viçosa MG 36570-900, Brazil; \\ mhcosta@ufv.br (M.H.C.); fernando.m.pimenta@ufv.br (F.M.P.); vitor.fontes@ufv.br (V.C.F.); \\ vfabrito@hotmail.com (V.F.A.d.B.); maricastrodasilva@gmail.com (M.C.) \\ * Correspondence: raphaelpousa@gmail.com; Tel.: +55-31-3899-1902
}

Received: 29 March 2019; Accepted: 30 April 2019; Published: 2 May 2019

check for updates

\begin{abstract}
In Western Bahia, one of the most active agricultural frontiers of the world, cropland area and irrigated area are increasing at fast rates, and water conflicts have been happening at least since 2010. This study makes a hydroclimatic analysis of the water resources in Western Bahia, from both supply and demand viewpoints. Time series of precipitation for the period 1980-2015 and river discharge for the period 1978-2015 are analyzed, indicating a significant reduction of up to $12 \%$ in rainfall since the 1980s, and a reduction in river discharge in all stations studied, in both the rainy season and the dry season. Combined with that, irrigated area has increased over 150-fold in 30 years, and in the most irrigated regions, has increased by $90 \%$ in the last eight years only. Seven regions in Western Bahia have been identified where the potential for water use conflicts is critical. Moreover, the combination of reduced availability and increased demand of water resources indicates that, if current trends are maintained, conflicts over water may become more frequent in the next years or decades. A short-term alternative to avoid such conflicts is to largely avoid irrigation during the months with low discharge. However, a monitoring system in which the availability and demand of water resources for irrigation are actually measured and monitored, is the safest path to provide water security to this region.
\end{abstract}

Keywords: climate change; MATOPIBA agricultural frontier; water security; hydroclimatic analysis; water conflicts

\section{Introduction}

The relationship between water and conflict is an area of continued interest and debate in both the policy and water resources literature and in the popular press [1]. Conflicts arise by several socioeconomic, political, or biophysical causes, including proximity to the water source, government type, aridity, climate variability and change, and rapid population growth. The dispute becomes much more challenging when there are multiple causes for the conflict. This work provides a case study of a region where two factors, climate change and intense irrigation growth, contribute to increased friction on the use of water resources: Western Bahia, in Brazil.

The western part of the state of Bahia is one of the most active agricultural frontiers of the world, where land use transition started in 1985 [2]. Western Bahia (Figure 1) is part of a wider region called MATOPIBA (acronym formed by the states of Maranhão, Tocantins, Piauí, and Bahia), an agricultural frontier in the Cerrado biome in Brazil, and characterized by rapid changes in land cover and land use for cropland, especially soybean, and agricultural intensification through the adoption of new 
technologies, leading to high yields. In Western Bahia, cropland area has reached 2 million hectares in the 2016/2017 growing season, mainly soybeans, cotton, and maize [3].

A major difference between Western Bahia and the rest of MATOPIBA is that the impressive extensification has been followed by a no less impressive increase in irrigated area, which grew from 9 pivots in 1985 to 1550 center pivots in 2016 [4]. The region includes three river basins (Rio Grande, Rio Corrente, and the northern part of the Rio Carinhanha), all tributaries of the São Francisco River, and also sits on the top of the Urucuia aquifer [5], a vast geological formation that is connected to the rivers, and helps regulate their seasonality and interannual variability. Five small hydroelectric plants operate in the region, all on tributaries of the Rio Grande upstream of the town of Barreiras (Figure 1), with power ranging from $450 \mathrm{~kW}$ to $25 \mathrm{MW}$ [6].

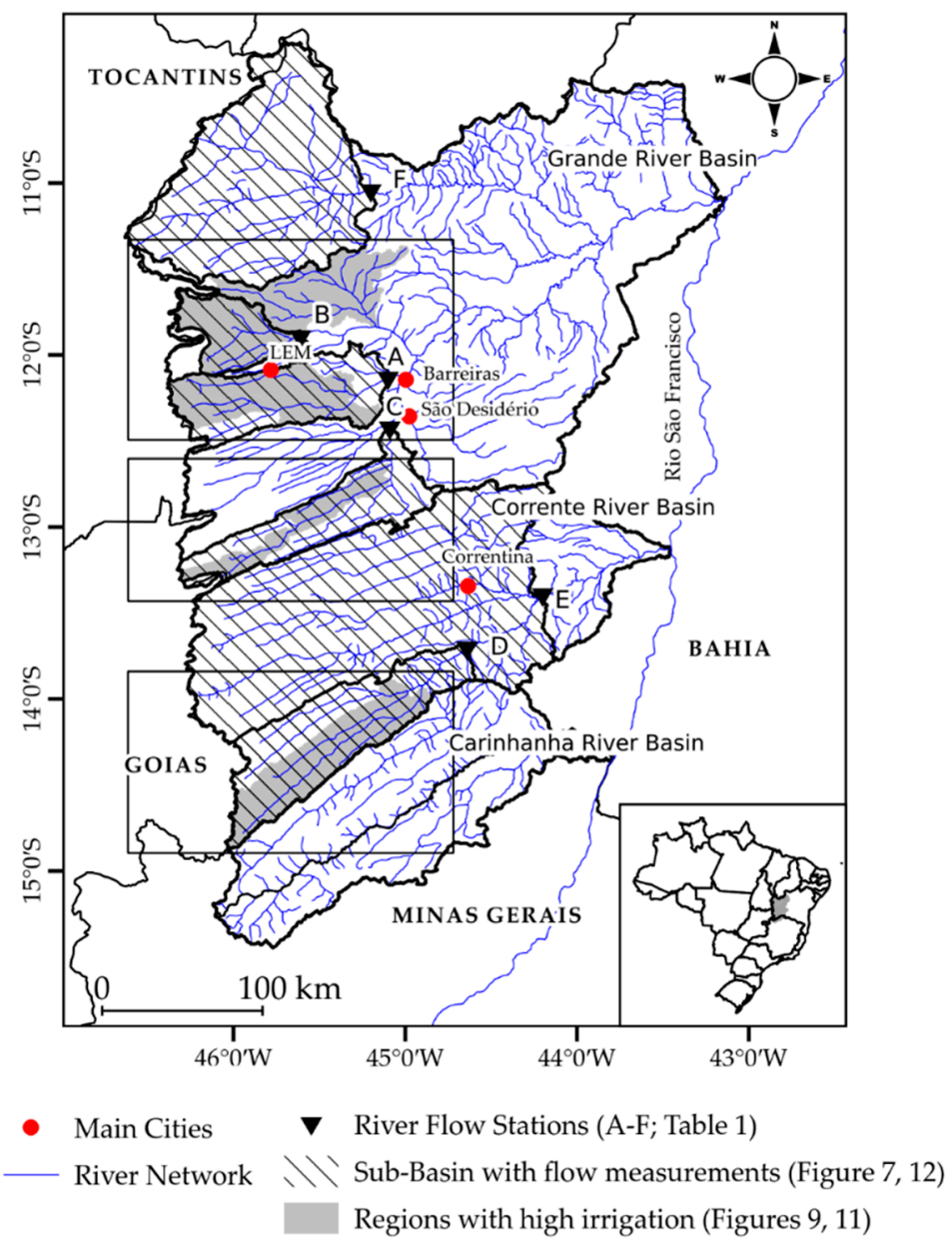

Figure 1. Study area representing the river networks, sub-basins with flow measurements analyzed in this study (hatched areas), regions with high irrigation (gray areas), and the location of main towns. LEM is the town of Luis Eduardo Magalhães. The rectangles represent the zoom areas detailed in Figure 5. River flow stations A-F are described in Table 1.

The long-term (1980-2015) precipitation, evapotranspiration, and runoff for the region are $1060 \mathrm{~mm}_{\text {year }}{ }^{-1}, 860 \mathrm{~mm}_{\text {year }}{ }^{-1}$, and $200 \mathrm{~mm}_{\text {year }}{ }^{-1}$, respectively. However, the region is located in the transition between the seasonally dry Cerrado biome to the west (annual precipitation $>1200 \mathrm{~mm}_{\text {year }}{ }^{-1}$ and a six-month rainy season, from mid-October to mid-April) and the semi-arid Caatinga biome to the east (annual precipitation $<800 \mathrm{~mm} \mathrm{year}^{-1}$ and a four-month rainy season). Precipitation, evapotranspiration, and runoff are seasonal. Precipitation typically varies from $0-10 \mathrm{~mm} \mathrm{month}^{-1}$ in the driest months (June, July, August) to about $150-200 \mathrm{~mm} \mathrm{month}^{-1}$ in the rainiest months (December and January). Monthly evapotranspiration (from MODIS MOD16 product) typically varies between 
$20 \mathrm{~mm} \mathrm{month}^{-1}$ in September and $85 \mathrm{~mm} \mathrm{month}^{-1}$ in February. Despite the high seasonality in precipitation, the seasonal variability in runoff is relatively small, with maximum discharge about three times greater than the minimum discharge, which is an indication of the strong regulation provided by the Urucuia aquifer. Temperatures and solar radiation are high around the year and, with the aid of irrigation, would allow for year-round crops (five to six crop growing seasons in two years), limited only by phytosanitary regulations. These circumstances have contributed to the intense growth of irrigation in the region [7].

Conflicts over the use of water have become common in the region in the last decade, however few of them have been documented. Maybe the first documented conflict happened in 2010. The hydropower station Sitio Grande on the Rio das Fêmeas, a tributary of the Rio Grande, is the largest plant in the region and has a water permit of $12 \mathrm{~m}^{3} \mathrm{~s}^{-1}$, the largest water permit in the region, about $1 / 3$ of the water rights granted in the Rio Grande basin [8]. Despite being the largest grant, this is a non-consumptive use of water, as the water is not withdrawn from the river, but instead it must be available at the river to flow through the turbines. The conflict happened during the initial filling of the lake, which interrupted the flow of the river for several days with environmental and social consequences.

Conflicts kept being reported informally through social networks, personal communications, etc. Another formal documentation happened in 2015, an El Niño year when the region experienced a severe drought (2015 annual rainfall was $674 \mathrm{~mm}$, one of the lowest on record). On 11 December 2015, the Rio Corrente Basin Committee requested a temporary suspension on the concession of water use permits on the basin until further criteria for water permits on the basin are defined [9]. On 2 November 2017, the usually peaceful town of Correntina (population 32,000) made the national headlines [10], when about 500 people invaded one farm that received recent irrigation systems and destroyed a significant part of their facilities and equipment as a way of protesting against the appropriation of water by agribusiness. A week after, on 11 November, approximately 10,000 people marched peacefully through Correntina, in defense of the Rio Corrente and its tributaries [11].

Although the water use conflicts in the region are usually attributed to the immense growth rate of irrigation systems, climate variability may also play an important role. Being in the transition between the semi-arid and the seasonally dry tropical climate regions, Western Bahia may be a serious candidate for climate change. This study makes an hydroclimatic analysis of the water resources in Western Bahia, from both the supply and demand viewpoints.

\section{Data and Methods}

Data and methods used in this analysis are summarized in Figure 2. Long-term time series of precipitation and river discharge are analyzed to evaluate the availability of water resources for irrigation, while maps of irrigation areas and interviews with irrigators are produced to evaluate the demand of water resources. We conclude with recommendations to improve water management and avoid further water conflicts. 


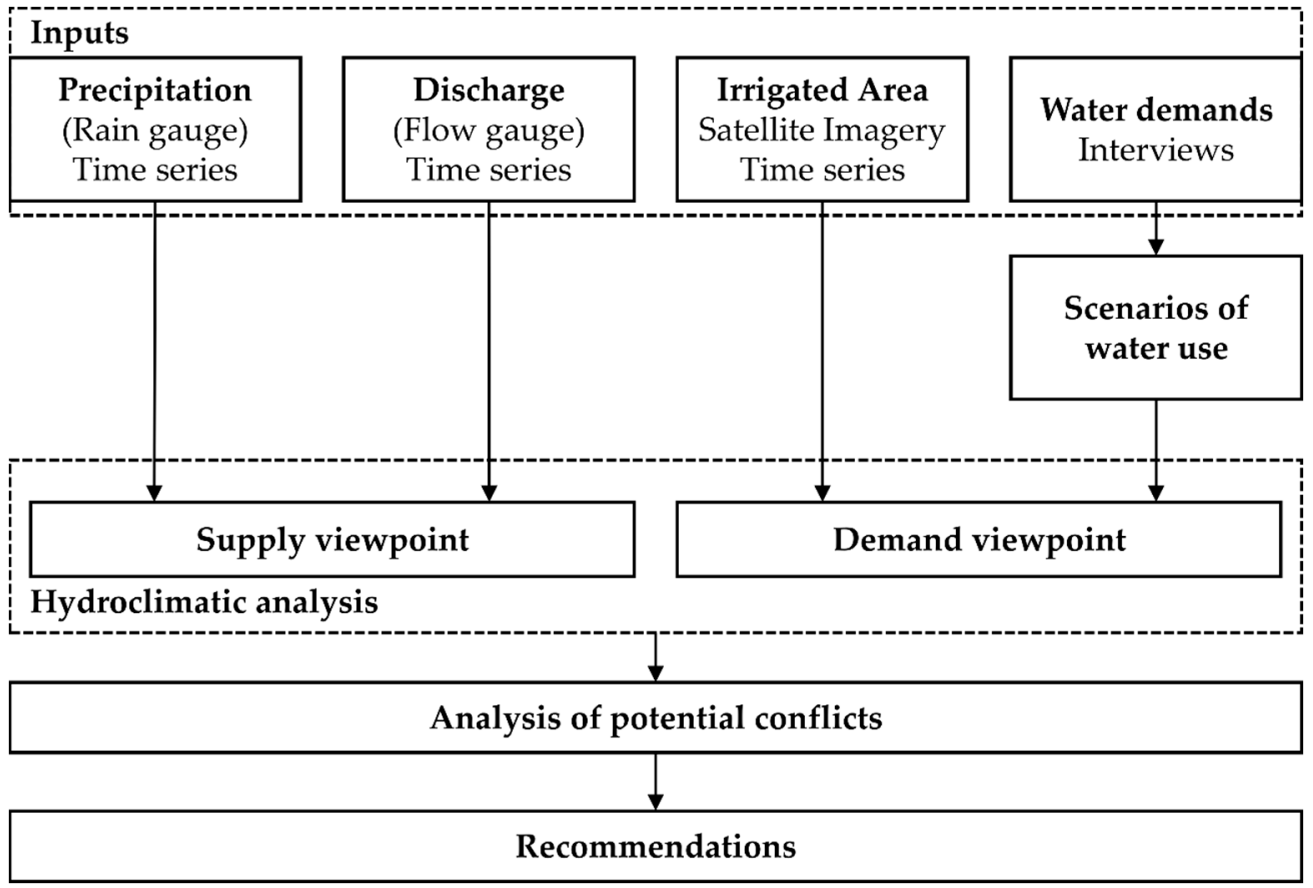

Figure 2. Flowchart illustrating the data and methods.

\subsection{Precipitation and River Flow Data}

Precipitation data in the region have been available through the INMET (Instituto Nacional de Meteorologia) and ANA (Agência Nacional das Águas) weather station and rain gauge networks since the 1930s, but the network was sparse and the time series were frequently interrupted. A somewhat dense network was available only in the late 1970s. To characterize regional patterns, the daily precipitation dataset of Xavier et al. [12] was used, which is available at a grid resolution of $0.25 \times 0.25$ (approximately $28 \mathrm{~km} \times 28 \mathrm{~km}$ ) for a 36-year period of 1980-2015. This dataset was assembled from the available rain gauge, conventional, and automatic weather stations. Original data were quality-controlled, and six different interpolation methods were tested (average of the five nearest data points; natural neighbor; thin plate spline; inverse distance weighting; angular distance weighting; and ordinary point kriging). The accuracy of the interpolation methods was evaluated by a cross-validation procedure, in which an observed data point was temporarily removed from the database, and then used to test the estimated value by each interpolation method at the location of the station. Angular distance weighting was considered the method with best skill $[12,13]$. To evaluate longer trends (before 1980), the station of Barreiras (WMO code 83236) was also used, which has nearly continuous data since 1961.

The daily river flow data $\left(\mathrm{m}^{3} / \mathrm{s}\right)$ used are provided by ANA. The fluviometric data are available since the 1930s, with a low density of stations and significant gaps. From 1930s to 1970s, there are about $30 \%$ of gaps in the data series and some discontinued stations. Quantity and quality of data increased in the 1970s, with only $2 \%$ of gaps, and we initially selected 25 river flow stations with few gaps since 1978 .

The granting of water use permits in the Grande and Corrente basins is an attribution of the State of Bahia, which uses the criterion that $80 \%$ of $Q_{90}$ can be granted for human use (according to State Decree number 6296 of 21 March 1997). $Q_{90}$ is the flow expected to be present in the river during at least $90 \%$ of the time, i.e., during $90 \%$ of the time series used in the calculation, there is a flow equal or greater than $\mathrm{Q}_{90}$ in the river.

To follow this criterion, our analyses of water availability are based on the flow duration curve of specific sections of the rivers. A flow duration curve is a cumulative frequency curve that shows the percent of time specified discharges were equaled or exceeded during a given period. Here, $\mathrm{Q}_{90}$ was 
calculated using the long-term series ( $\mathrm{LT}_{90}$ ), which is a more common criterion for granting water use permits, but we also calculate $Q_{90}$ using two periods, to characterize hydroclimate change.

Although we analyzed data for 25 fluviometric stations, six stations were selected for a deeper analysis (Table 1, Figure 1). These stations are spread throughout the region and are representative of the regional variability. Moreover, four stations were chosen because they have dense irrigation systems upstream (A-D), while two of them $(\mathrm{E}, \mathrm{F})$ were chosen for their low irrigation density upstream.

The flow stations drain relatively large areas, and (with the exception of station $B$ ) may not be representative of the densest irrigated areas. Thus, seven ottobasins with the highest concentration of center pivots (represented by gray areas in Figure 1) were also analyzed. Ottobasins, or Otto-codified hydrographic basins, are areas of contribution of the stretches of the hydrographic network coded according to the topological system proposed by Otto Pfafstetter [14,15] and officially adopted by ANA to uniquely identify contribution areas in any watershed using a simple 10-base code. The system is hierarchical and recursive, and the higher number of digits in the ottobasin code implies a higher level of sub-division of a watershed.

Table 1. Selected river flow stations. The letters correspond to the labels of stations in Figure 1.

\begin{tabular}{|c|c|c|c|c|c|c|}
\hline & $\begin{array}{l}\text { ANA } \\
\text { Station } \\
\text { Code }\end{array}$ & River & Station Name & Municipality & $\begin{array}{c}\text { Drainage } \\
\text { Area }\left(\mathbf{k m}^{2}\right)\end{array}$ & $\begin{array}{c}\text { Station } \\
\text { Coordinates }\end{array}$ \\
\hline B & 46570000 & Rio de Janeiro & Ponte Serafim & Barreiras & 2522.118 & $11^{\circ} 54^{\prime} \mathrm{S}, 45^{\circ} 36^{\prime} \mathrm{W}$ \\
\hline $\mathrm{C}$ & 46415000 & Rio Grande & Sítio Grande & São Desidério & 4943.866 & $12^{\circ} 25^{\prime} \mathrm{S}, 45^{\circ} 05^{\prime} \mathrm{W}$ \\
\hline $\mathrm{D}$ & 45840000 & Rio Formoso & Gatos & Jaborandi & 7132.696 & $13^{\circ} 42^{\prime} \mathrm{S}, 44^{\circ} 38^{\prime} \mathrm{W}$ \\
\hline
\end{tabular}

\subsection{Statistical Tests}

We applied four statistical analyses to detect changes in the rainfall time series. First, we applied the non-parametric Pettitt's test [16] for detecting changing points to the region-wide precipitation time series. This is a rank-based and distribution-free test for detecting a significant change in the mean of a time series and it is particularly useful when no hypothesis is required about the location of the changing point. The Pettitt test has been widely applied to detect changes in the observed hydroclimatic time series [17,18], and can only be applied to continuous time series. Considering a sequence of random variables $X_{1}, X_{2}, \ldots, X_{T}$, which have a change point at $t=\tau$. As a result, $\left(X_{1}, X_{2}\right.$, ..., $\left.\mathrm{X}_{\tau}\right)$ have a common distribution function $\mathrm{F}_{1}(\mathrm{X})$, but $\left(\mathrm{X}_{\tau+1}, \mathrm{X}_{\tau+2}, \ldots, \mathrm{X}_{\mathrm{T}}\right)$ are distributed as $\mathrm{F}_{2}(\mathrm{X})$, where $F_{1}(X) \neq F_{2}(X)$. The null hypothesis $H_{0}$ for this test is that the observations are independent and identically distributed (no change, or $\tau=\mathrm{T}$ ), and is tested against the alternative hypothesis $\mathrm{H}_{1}$ : change (or $1 \leq \tau<\mathrm{T}$ ); using the non-parametric statistic $\mathrm{K}_{\mathrm{T}}=\max \left|\mathrm{U}_{\mathrm{t}, \mathrm{T}}\right|$ where:

$$
\mathrm{U}_{\mathrm{t}, \mathrm{T}}=\sum_{\mathrm{i}=1}^{\mathrm{t}} \sum_{\mathrm{j}=\mathrm{t}+1}^{\mathrm{T}} \operatorname{sign}\left(\mathrm{X}_{\mathrm{t}}-\mathrm{X}_{\mathrm{j}}\right) .
$$

The confidence level for a change-point is defined as

$$
\rho=\exp \left(\frac{-6 \mathrm{~K}_{\mathrm{T}}^{2}}{\mathrm{~T}^{3}+\mathrm{T}^{2}}\right)
$$

Second, we applied a classical Student's $t$-test to test the null hypothesis that the annual mean precipitation is not significantly different from one period to the other, where periods are divided at $\mathrm{t}=\tau$, obtained by the Pettitt's test.

Third, we applied the Mann-Kendall test for trends in the time series, a non-parametric, distribution-free test that makes no assumptions of linearity or distribution of the values. This test has 
been recommended widely by the World Meteorological Organization for general trend analysis of time series [19]. Finally, we used box plots to evaluate the interannual variability of precipitation.

\subsection{Irrigated Area}

The irrigated area by center pivots was obtained by a four-step procedure. First, imagery from Landsat 5, 7, and 8 for the period 1990 to 2018 was processed using the Google Earth Engine cloud. The images were filtered using the median of the pixels for the dry period (April to September) and mosaicked for the study region, to produce a single region mosaic per year. Second, the filtered map was merged with the center pivots data from Landau et al. [20] and from the OpenStreetMaps project to obtain an initial pivots map of the region. Then, duplicated features and topology errors were removed from the dataset. Third, with the aid of the visible bands (RGB) and the normalized difference vegetation index (NDVI) from the generated mosaics, the center pivot features were digitized or erased according to the recognition in the images of each year. Finally, the annual center pivot geometries went through a trend and precision analysis of their positional components for positional accuracy validation, producing a final map without trends in center pivot sizes and with accuracy adequate to the scale of 1:150,000, compatible with the resolution of the Landsat images.

The resulting yearly maps for Western Bahia were further processed at the ottobasin scale, to select only the highly irrigated regions, i.e., ottobasins with at least $4 \%$ of their total area irrigated in 2018. A total of seven regions were selected (gray areas in Figure 1).

\subsection{Calculations of Regional Water Demand for Irrigation}

The regional water uptake for irrigation depends on (1) the effective area irrigated at some time $\left(\mathrm{A}_{\mathrm{I}}\right)$, in $\mathrm{km}^{2}$; (2) the reference evapotranspiration rate $\left(\mathrm{ET}_{\mathrm{o}}\right)$, in $\mathrm{mm} /$ day; (3) the crop being irrigated and its stage of development, which are integrated into an adimensional "crop coefficient" $\mathrm{K}_{\mathrm{c}}$, that usually varies between 0.3 and 1.3; and (4) the efficiency of the system $(\varepsilon)$, which for center pivots is typically around 0.8 . The water uptake for irrigation $\left(\mathrm{Q}_{\mathrm{I}}\right)$ in $\mathrm{m}^{3} \mathrm{~s}^{-1}$ is the product of these four terms:

$$
\mathrm{Q}_{\mathrm{I}}=\frac{\mathrm{A}_{\mathrm{I}} \mathrm{K}_{\mathrm{c}} \mathrm{ET}_{\mathrm{o}}}{86.4 \varepsilon} .
$$

Although we have mapped all center pivots in these regions, our estimates of irrigated area should be understood in terms of area with installed irrigation systems. These systems may be used fully, partially, or not at all, depending on the year and the season. Currently, there are no regionally consolidated data of the actual amount of irrigated area nor the crops planted per center pivot as a function of time.

To overcome this limitation, we interviewed 20 irrigators and one irrigation consultant (who consulted for several tens of irrigators). Interviews were conducted between July 2018 and October 2018 , either in person or by phone. We asked questions about the frequency of irrigated crops a year, typical planting dates, crops planted, amount of irrigation applied, and the main reasons why they make their management decisions.

\section{Results}

\subsection{Changes in Precipitation}

Figure 3 shows the evolution of annual mean regional precipitation for the three basins. In addition, data for the Barreiras station are also shown. An analysis of Figure 3 indicates that two main characteristics of these time series stand out. First, annual mean precipitation presents strong interannual variability, ranging from $\sim 600$ to $>1700 \mathrm{~mm}_{\text {year }}{ }^{-1}$. In other words, individual precipitation years range from values typical of the semi-arid climate east of the region to values typical of the tropical seasonally dry climate west of the region. The interannual variability pattern is also consistent across the three basins, which indicates that it is large-scale driven. In addition, the regional pattern 
correlates well with the data at the Barreiras station, which allows for speculative interpretations in the period before 1980 .

Second, basin-wide precipitation has not been greater than $1370 \mathrm{~mm} \mathrm{year}^{-1}$ since 1992, while this level has been exceeded five times between 1980 and 1992, and another five times in the period from 1961 to 1979, if considering the Barreiras data. This is a major shift in the precipitation regime, that affects the regional decadal means. To be sure, we applied the non-parametric Pettitt's test for detecting changing points to the region-wide 1980-2015 time series, which confirms a changing point at $\tau=13(1992)$, with $K_{\mathrm{T}}=87$ and significance level $4.6 \times 10^{-9}$.

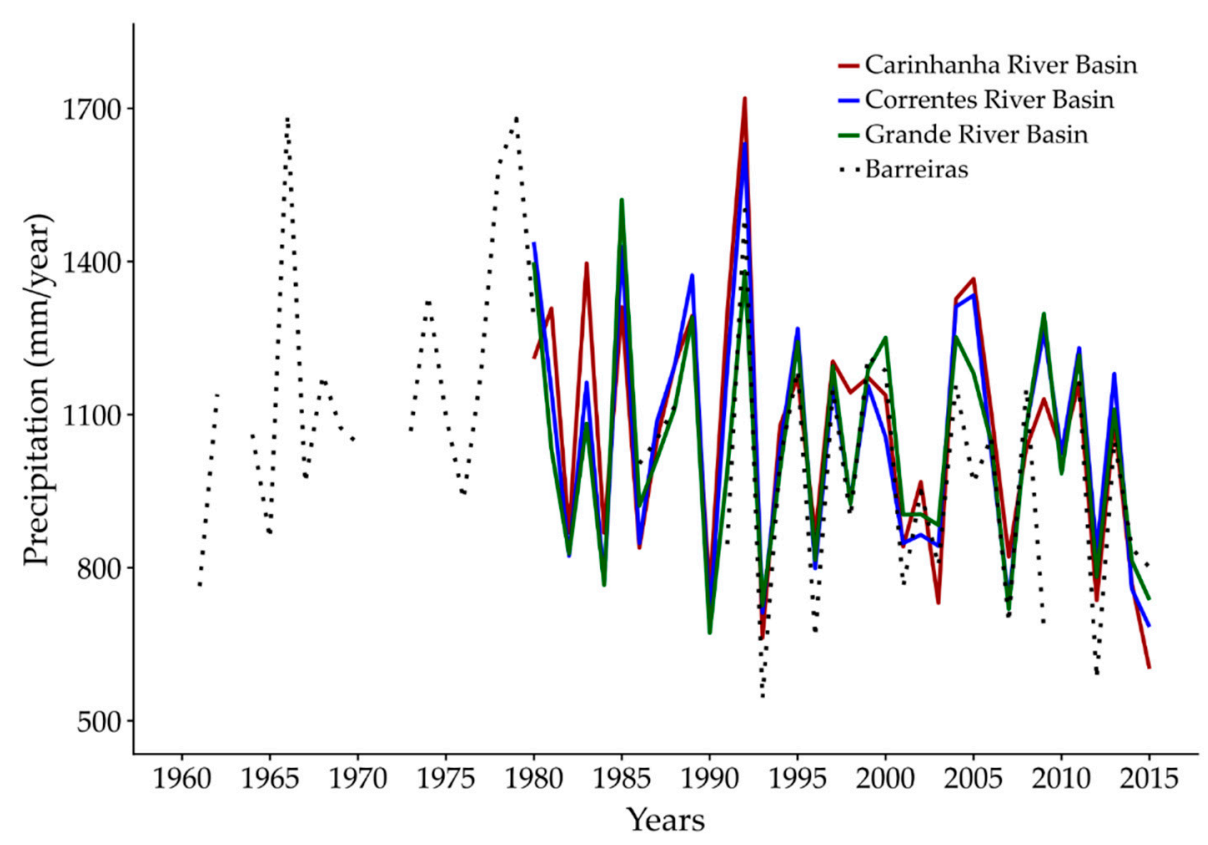

Figure 3. Annual mean precipitation for the three basins and historical precipitation for the Barreiras rain gauge.

Based on this evidence, the 36-year time series of rainfall and river flow were divided in two periods, namely P1 (1980-1992) and P2 (1993-2015), to test the hypothesis of precipitation change between the two periods. We also tested other divisions of the rainfall time series (two periods of 18 years, three periods of 12 years), but the division in P1 and P2 was the choice that yielded the highest significance in precipitation change.

Indeed, the regional patterns of mean precipitation for the two periods (P1, P2) show that isohyets are moving westward from $\mathrm{P} 1$ to $\mathrm{P} 2$ (Figure $4 \mathrm{a}, \mathrm{b}$ ), translating into a regional drying from $\mathrm{P} 2$ with respect to P1 (Figure 4c). Although the period of analysis is relatively small, significant precipitation change has been detected. Extremely likely $(\alpha=0.05)$ precipitation reduction, averaging $-165 \mathrm{~mm}^{-1}$ year $^{-1}(-12 \%$ compared to P1 mean), appears in a core area in the west of the region. This core area is surrounded by very likely $(\alpha=0.10)$ precipitation changes (Figure $4 c$ ), and average drier conditions throughout nearly all the region (Figure 4c). Moreover, the Mann-Kendall trend test indicates precipitation trends consistent both in sign and in significance with the precipitation differences (Figure 4d).

Considering basin-wide averages, the significant reduction in precipitation has happened mainly in the months with higher precipitation (December and January) in the three basins (Figure 5, $\alpha=0.05$ ). In addition, the interannual variability of precipitation, measured by both the interquartile difference and the range of variability, has also decreased in the three basins in P2, when compared to P1 (Figure 6). 


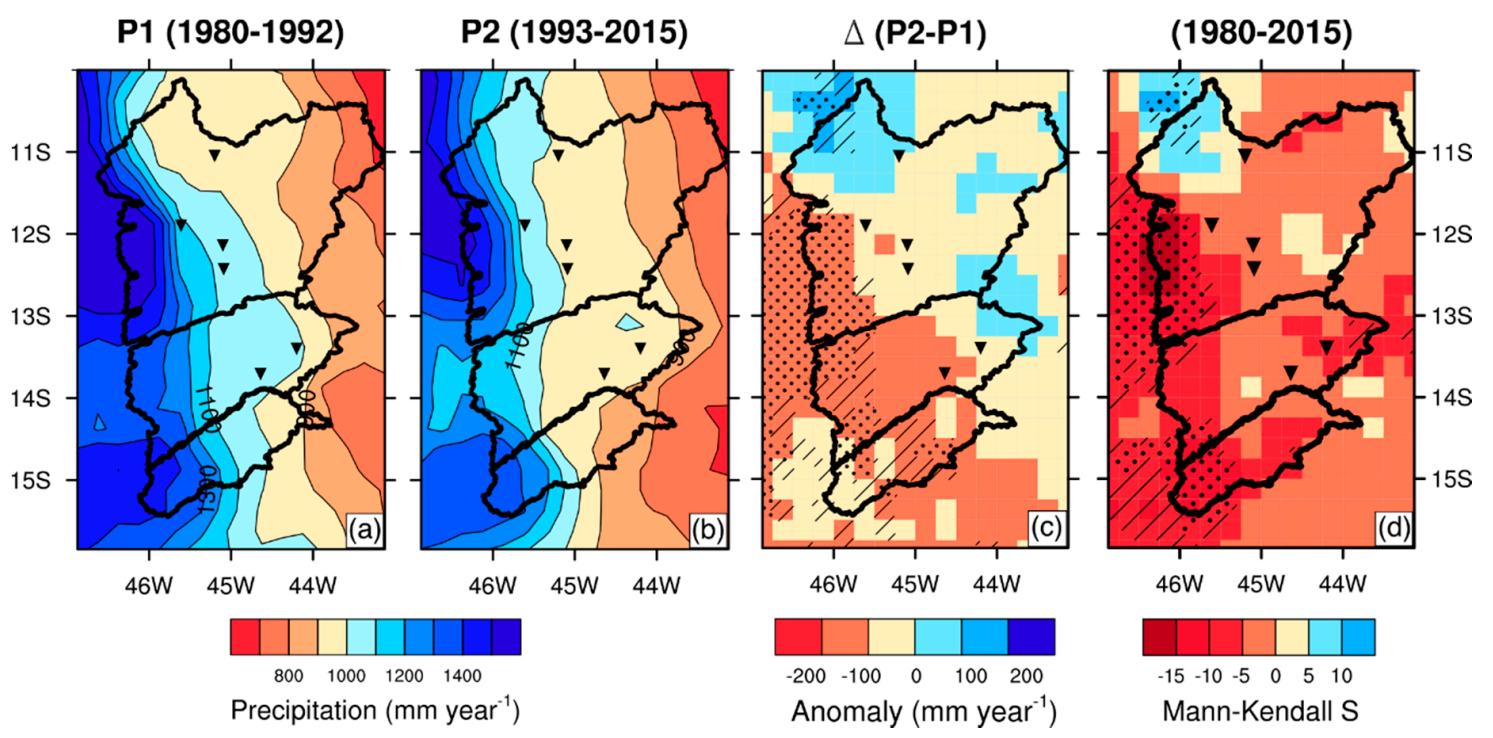

Figure 4. Average precipitation map for periods P1 (a), P2 (b) the difference between P2 and P1 (c), and the Mann-Kendall S statistic (negative values represent decreasing trends). The six selected river flow stations are also shown. Dotted areas represent differences significant at $\alpha=0.05$, according to Student's $t$ test (in c), or according to the Mann-Kendall test (in d), while shaded areas represent differences or trends significant at $\alpha=0.10$.

(a) Grande River Basin

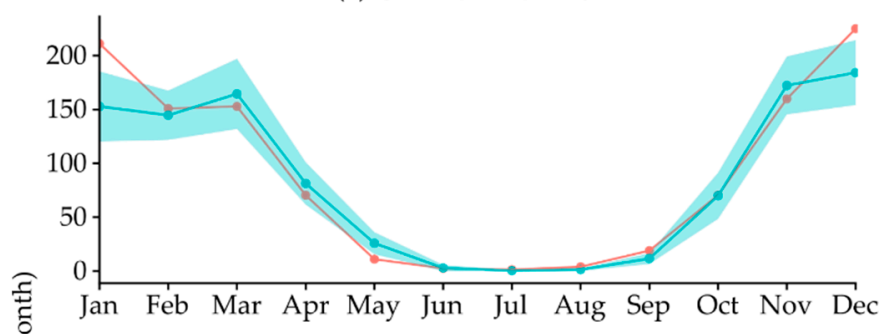

(b) Corrente River Basin

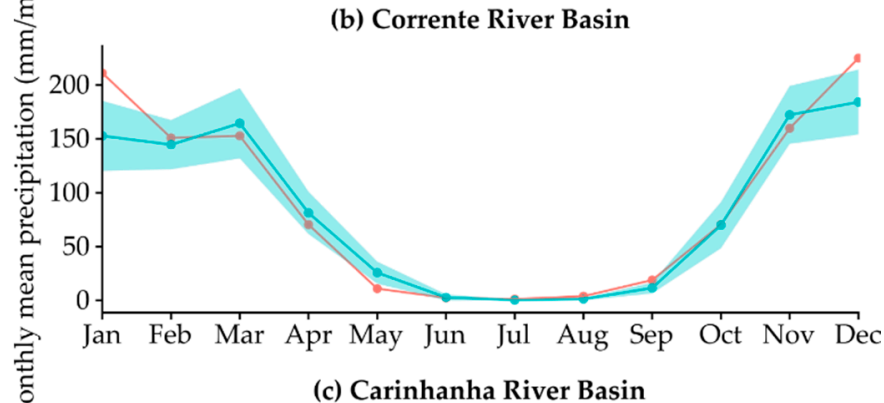

c) Carinhanha River Basin

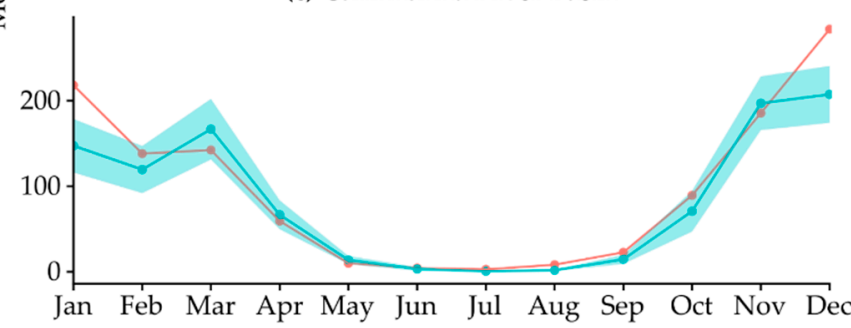

$\rightarrow P 1 \rightarrow P 2$

Figure 5. Monthly mean precipitation for two periods (P1 and P2) for the three basins. The shaded area in P2 is the confidence interval for the mean $(\alpha=0.05)$. Averages in P1 outside the shaded area are statistically different at this level of confidence. 


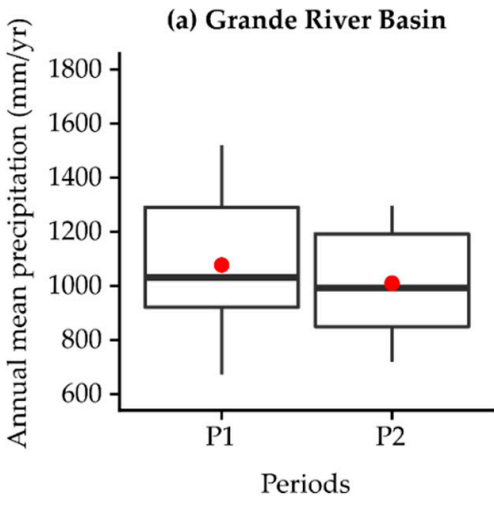

(b) Correntes River Basin

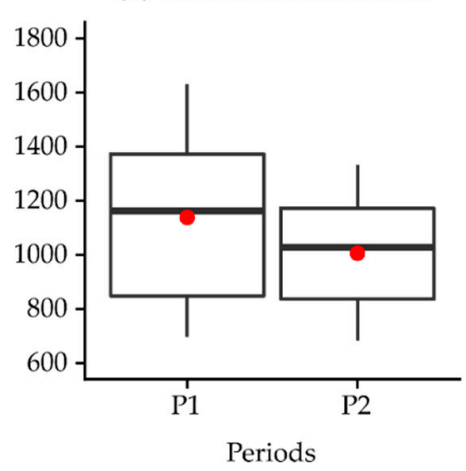

(c) Carinhanha River Basin

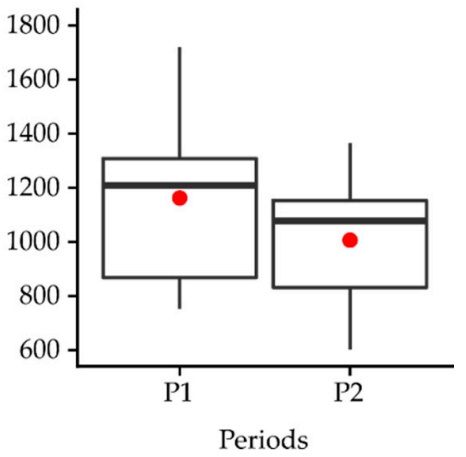

Figure 6. Boxplot displaying the median (thick lines), the lower and upper quartile (box), the mean (red dots), and the minimum and maximum of the distribution (whiskers) for annual values of precipitation in periods P1 and P2. Period P1, although much shorter than P2, has higher interannual variability.

Two main large-scale systems are likely the cause of the reduced rainfall in this region, both linked to higher interannual variability and more extreme drought years [21]. First, the warming of the tropical North Atlantic Ocean leads to a higher frequency of anomalously northward positions of the intertropical convergence zone (ITCZ). In addition, changes in the temperature of the Pacific manifested as extremes of the El Niño-southern oscillation (ENSO) are partially associated with extreme drought in the region [22,23].

We suggest that the strong interannual variability of precipitation is driven by the seasonal expansion of the subtropical high across northeast Brazil. In dry years (El Niño years and warmer North Atlantic years), it expands more to the west, reaching the Bahia/Tocantins border. In wet years (La Niña years and cooler North Atlantic years), it expands less, staying to the east of the São Francisco River.

\subsection{Changes in River Flow}

The flow duration curves for the six stations analyzed in this work are presented in Figure 7. These curves show the percent of time specified discharges were equaled or exceeded during each period (P1, P2). All panels show that discharge has been decreasing at all levels of probability.

The discharge of these rivers is heavily regulated by the Urucuia aquifer. Parallel flow duration curves, like Figure 7c-f, indicate that the decrease in discharge is mainly caused by the reduction in rainfall, and modulated by the aquifer. While a monitoring piezometer network of the aquifer was set up only in 2011, by 2015 it already shows groundwater level drawdown of up to $5 \mathrm{~m}$ [24].

On the other hand, when the decrease in discharge is smaller in the wet season (lower percentiles) and higher in the dry season (higher percentiles), which is the case of Figure $7 \mathrm{~b}$, this is an indication that withdrawal of water during the dry season may be playing a relevant role in the decrease of discharge. It is no coincidence that station B (also region R2 in Table 2) is the one among the six selected with the highest density of irrigation upstream ( $4.8 \%$ of the upstream area irrigated), while the other ones have less than $1 \%$ of their drainage area irrigated. We suggest that water withdrawal for irrigation is only detectable in fluviometric records when irrigation upstream is between $1 \%$ and $4 \%$ of the drainage area of the station.

In addition, it can also be verified in Figure 7 that nearly all discharge data recorded during $\mathrm{P} 1$ in these six stations are higher than $\mathrm{Q}_{90}$ of $\mathrm{P} 2$. This means that, even considering the long term (1978-2015), $\mathrm{Q}_{90}$ is mostly defined by the discharges observed in P2 only. This is confirmed by Figure 8, which clearly shows that most of the situations when daily discharge $\mathrm{Q}$ is smaller than the long-term $\mathrm{Q}_{90}$ (LT $\mathrm{Q}_{90}$ ) happens after 2000. In an extreme case, station D in a very dry year like $2015,72 \%$ of the days (263 days out of 365) had daily Q lower than the LT Q90. Although this is a severe case, it is relatively common to find years when more than half of the days are below the LT $Q_{90}$. 

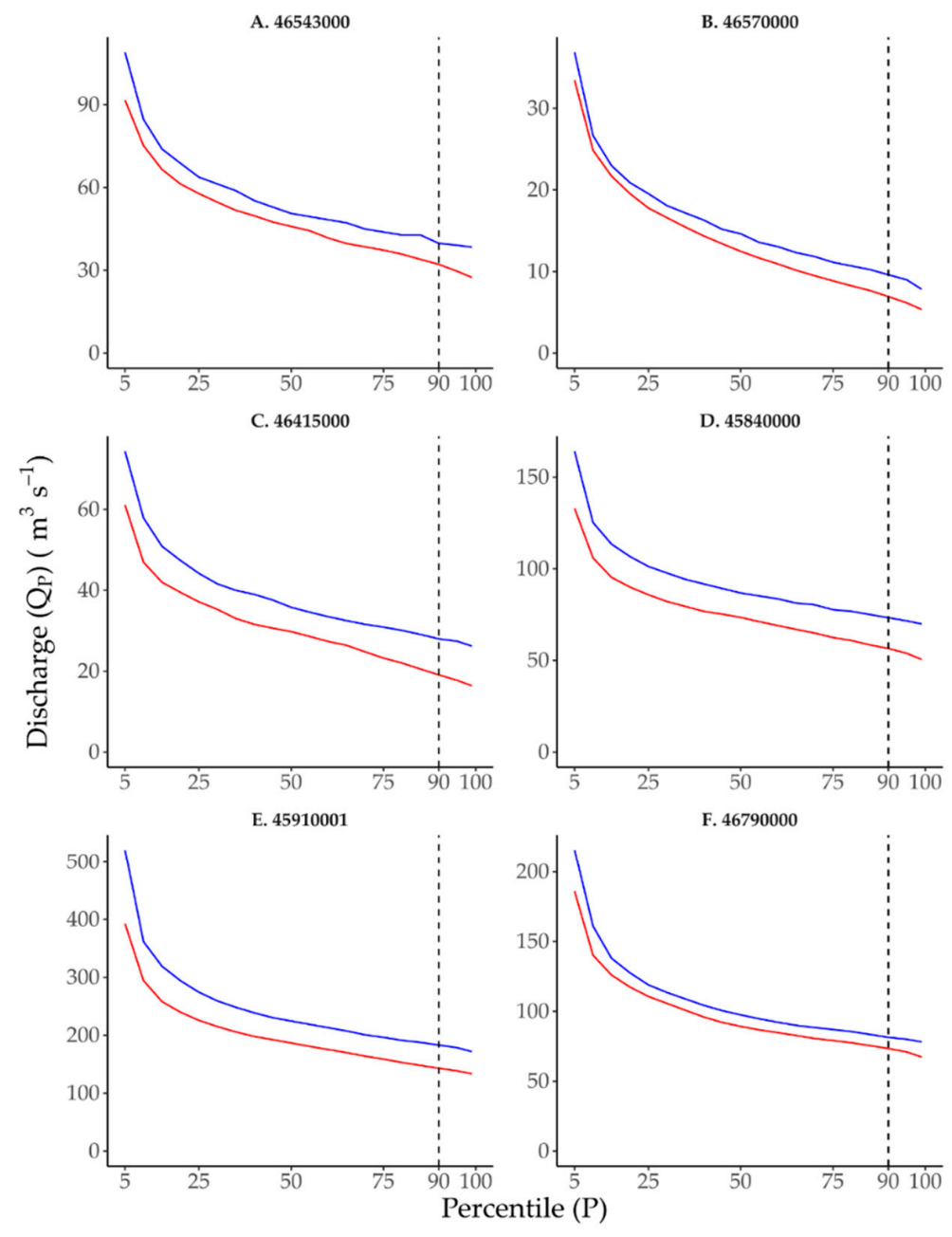

- P1: 1980-1992 - P2: 1993-2015

Figure 7. Flow duration curves for stations A-F for periods P1 and P2. Values in the x-axis are the probability that a given discharge $\left(Q_{p}\right)$ is exceeded during that period. The intersection of the dashed line, representing the $90 \%$ percentile, and each curve, represents the $Q_{90}$.

Our interpretation of these data is that, even if considering its relatively short (38 years) duration, all river discharge time series are non-stationary. Discharge has been decreasing all over the spectrum and throughout the region, minimum discharges have been defined in the most recent years, and even when the most recent dry years have been considered for the definition of minimum discharges, the actual recent rate of occurrence of a relatively unlikely phenomenon like $Q<Q_{90}$ is four to seven times higher than the expected probability. Under these circumstances, probability discharges cannot be used to predict the distribution of future flows. In addition, although the results are not shown here, the above characteristics are consistent across 24 of the 25 stations analyzed, except the northwesternmost station (upstream of station F), only area where precipitation did not decrease.

Non-stationarity can be explained by several factors, such as changes in river basins by anthropogenic effects, climate change, and low-frequency climate variability [25]. Moreover, this does not seem to be the case of uncertainty dominating the distribution of extremes, as suggested by Serinaldi and Kilsby [26]. The entire flow duration curve has shifted down, not only the extreme values. This is very much consistent with the picture of rivers regulated by a decreasing-level aquifer, following a reduction of the aquifer recharge after reductions in precipitation, arguably caused by a strengthening of the South Atlantic subtropical high-pressure system associated with the warming of the North Atlantic and Central Pacific, the ultimate causes for the non-stationarity. This is our 
current reasoning for the attribution of causes, although it can only be verified through detailed hydrogeological modeling and large-scale climate dynamics studies, which are beyond the scope of this work.

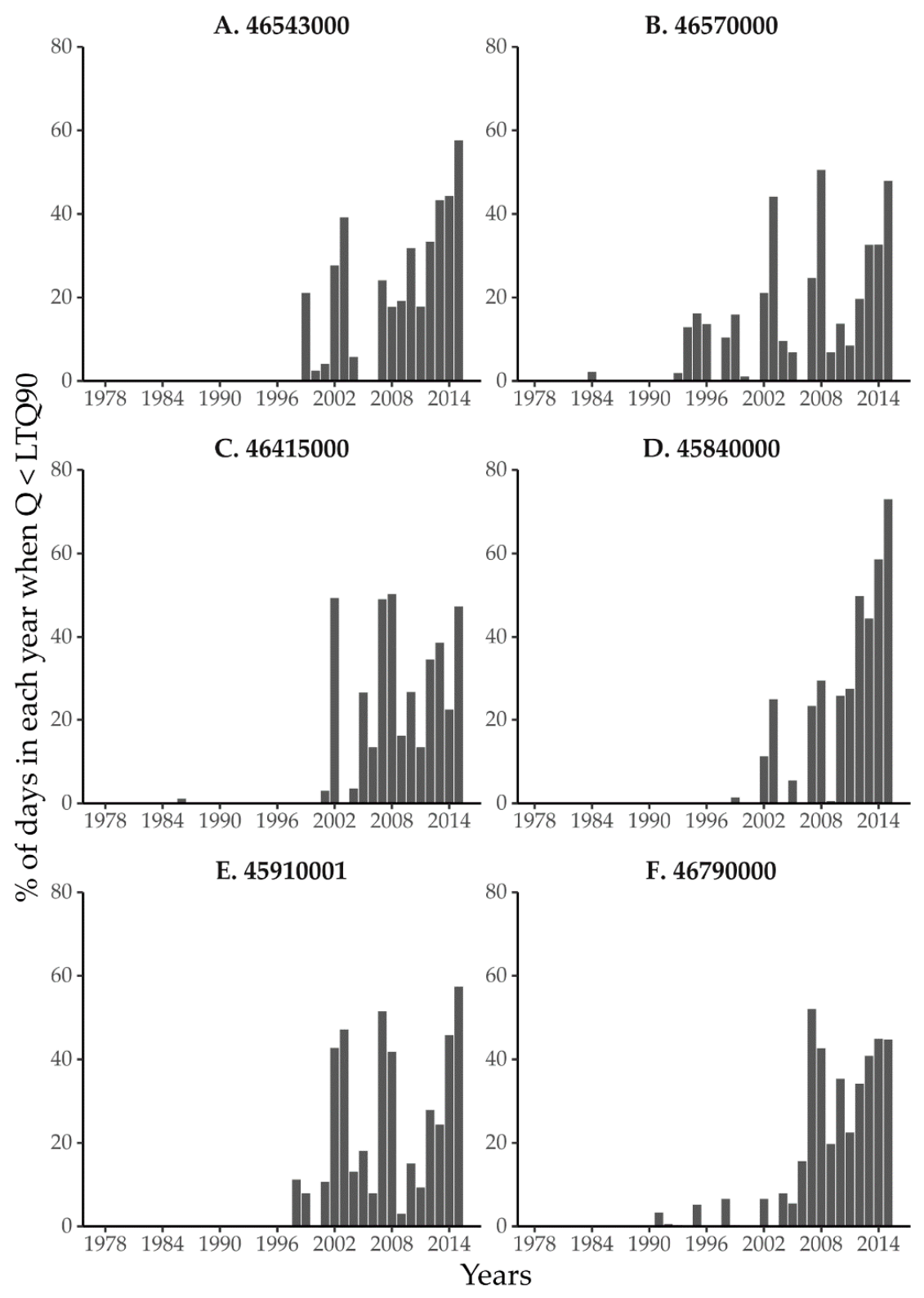

Figure 8. Percentage of days in each year when actual $Q$ is below the long-term $Q_{90}$. Long-term $Q_{90}$ is calculated for the period 1978-2015. The concentration of cases of Q $<$ LT (long-term) $Q_{90}$ after 2000 indicates drastic reductions in minimum discharges.

\subsection{Trends in Irrigated Area and Water Uptake on the River Flows}

To evaluate the effects of irrigation water uptake on the river flows, we choose seven regions with the highest concentration of irrigated area, where these effects are expected to be most significant. These seven regions have between $4.8 \%$ and $12.6 \%$ of the area of the ottobasin irrigated, while no other ottobasin in the region has more than $4 \%$. The spatial evolution in irrigated area in these regions (R1 to R7) is shown in Figure 9. The total irrigated area in these seven regions was $662.4 \mathrm{~km}^{2}$ in 2010, which increased to $1256.1 \mathrm{~km}^{2}$ in 2018 , a $90 \%$ increase in just eight years (Table 2). Figure 10 shows the temporal evolution of irrigated area for each region. Each region has a different pattern of growth, but all regions show a substantial increase in irrigation since the 1990s. 

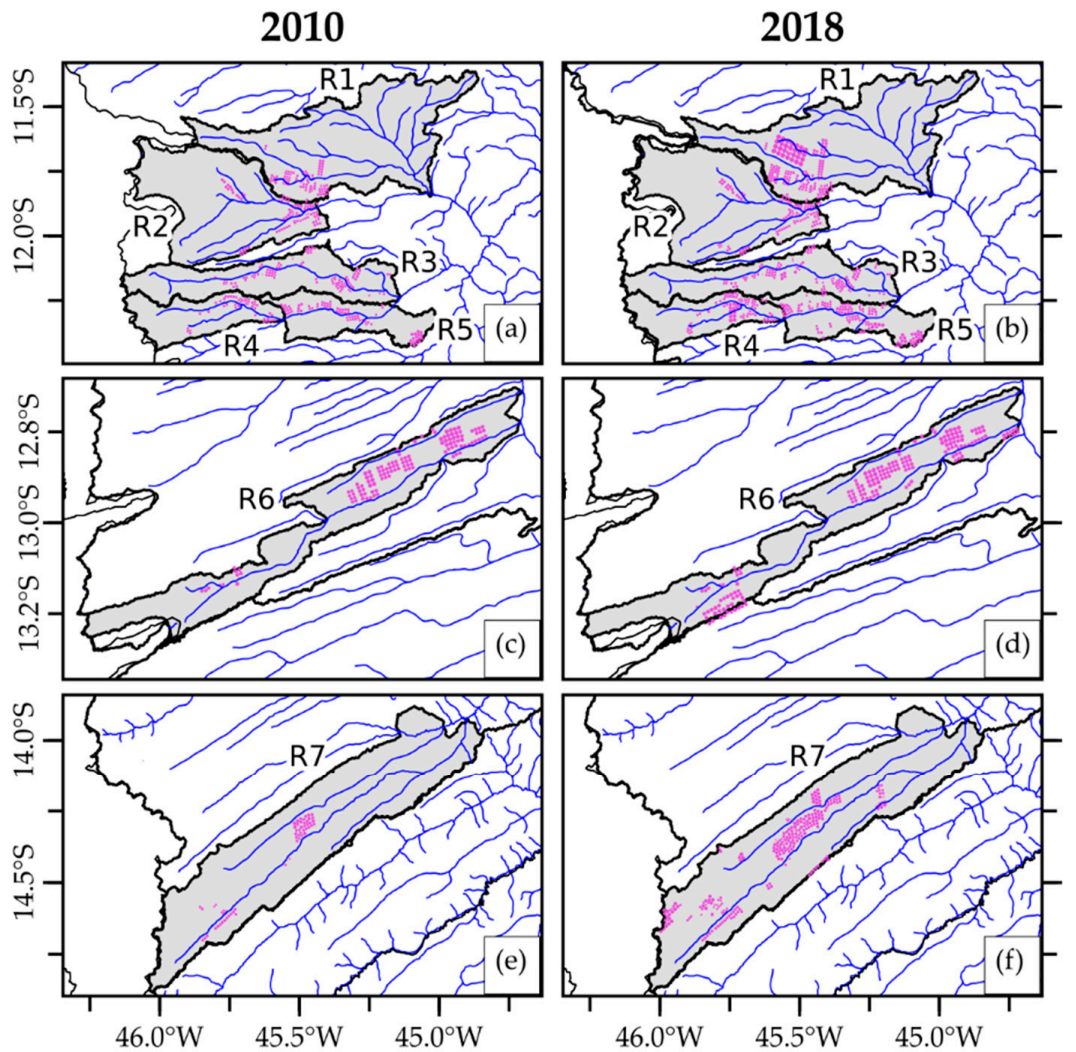

— River Network

Center Pivots

Selected Regions

Figure 9. Evolution of irrigated area for selected regions for 2010 and 2018. Each center pivot ranges from 26.9 ha to 355 ha in area. The North-South scale of (c) and (d) is different than the same scale of (a), (b), (e), and (f).

Table 2. Selected regions (R1-7) where irrigated area is located in Figure 9, with corresponding ANA Ottobasin codes. The region $\mathrm{R} 2$ coincides with the drainage area of station $\mathrm{B}$.

\begin{tabular}{|c|c|c|c|c|c|c|c|}
\hline \multirow{2}{*}{$\begin{array}{l}\text { Region } \\
\text { (Ri) }\end{array}$} & \multirow{2}{*}{$\begin{array}{c}\text { ANA } \\
\text { Ottobasin } \\
\text { Code }\end{array}$} & \multirow[b]{2}{*}{ River } & \multicolumn{2}{|c|}{ Total Area $\left(\mathrm{km}^{2}\right)$} & \multicolumn{3}{|c|}{ Irrigated Area in 2018} \\
\hline & & & Ottobasin & Region & $\begin{array}{c}\text { Ottobasin } \\
\left(\mathrm{km}^{2}\right)\end{array}$ & $\begin{array}{c}\text { Region } \\
\left(\mathbf{k m}^{2}\right)\end{array}$ & $\begin{array}{c}\% \text { of Total } \\
\text { Area }\end{array}$ \\
\hline R1 & 76243 & Rio Branco & & 3403.5 & 232.9 & 232.9 & $6.8 \%$ \\
\hline $\mathrm{R} 2$ & 46570000 * & Rio de Janeiro & & 2522.1 & & 122.2 & $4.8 \%$ \\
\hline R3 & 762641 & Rio Cabeceira de Pedras & & 1739.6 & & 108.6 & $6.2 \%$ \\
\hline $\mathrm{R} 4$ & 762691 & Rio Borá & & 938.3 & & 89.2 & $9.5 \%$ \\
\hline R5 & $\begin{array}{c}7626711 \\
762661 \\
762691\end{array}$ & $\begin{array}{c}\text { Rio de Ondas } \\
\text { Rio de Ondas mouth } \\
\text { Rio Borá (upstream) }\end{array}$ & $\begin{array}{c}778.64 \\
222.33 \\
938.3\end{array}$ & 1939.2 & $\begin{array}{c}121.1 \\
33.9\end{array}$ & 244.2 & $12.6 \%$ \\
\hline R6 & $\begin{array}{c}762891 \\
76489 \\
762871 \\
76285 \\
76282 \\
\end{array}$ & $\begin{array}{c}\text { Rio Grande } \\
\text { Rio Guará } \\
\text { Rio Grande } \\
\text { Rio Grande } \\
\text { Vereda Passaginha }\end{array}$ & $\begin{array}{l}197.10 \\
295.04 \\
361.45 \\
789.94 \\
431.66\end{array}$ & 2075.2 & $\begin{array}{l}42.0 \\
11.1 \\
42.1 \\
37.2 \\
62.3\end{array}$ & 194.7 & $9.4 \%$ \\
\hline R7 & $\begin{array}{c}764271 \\
76426 \\
764241\end{array}$ & $\begin{array}{l}\text { Rio Pratudão } \\
\text { Riacho do Váu } \\
\text { Rio Formoso }\end{array}$ & $\begin{array}{l}662.35 \\
702.94 \\
2499.73\end{array}$ & 3865.0 & $\begin{array}{c}14.3 \\
115.0 \\
134.9\end{array}$ & 264.2 & $6.8 \%$ \\
\hline
\end{tabular}

* Represents the fluviometric station code. 

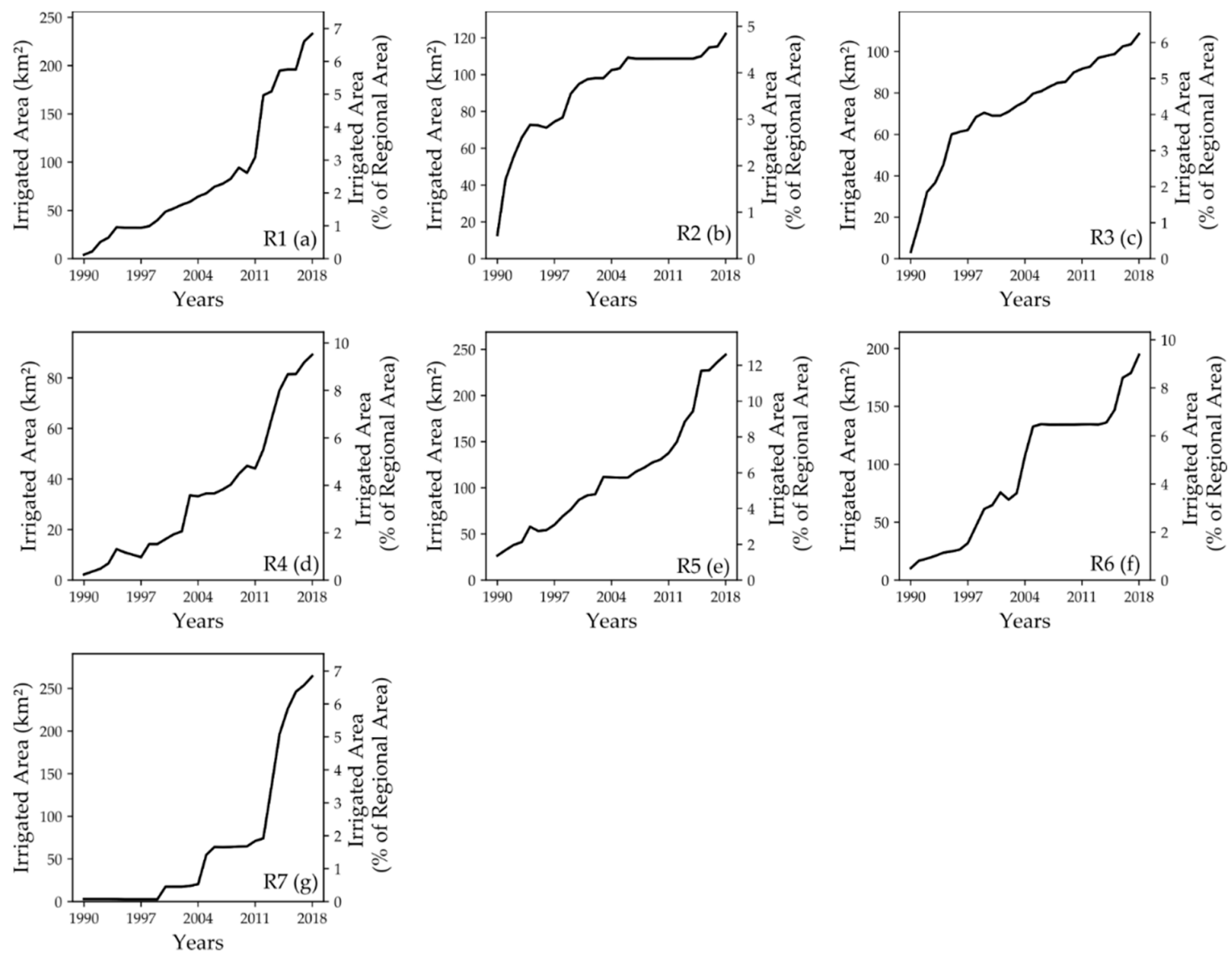

Figure 10. Evolution of irrigated area in selected regions, as defined in Figure 9 and Table 2.

With the area irrigated estimated and the areas with intense irrigation growth identified, in order to calculate water uptake, information on water demands per unit area are still needed (Section 2.4). From the interviews conducted, during the driest period of the year (September and October), when river discharge approaches $\mathrm{Q}_{90}$ values, water application rates $\left(\mathrm{K}_{\mathrm{c}} \mathrm{ET}_{\mathrm{o}} / \varepsilon\right)$ could be as high as $10 \mathrm{~mm} \mathrm{day}^{-1}$, if the irrigator had a high consumption crop like maize at the peak of the cycle $\left(\mathrm{K}_{\mathrm{c}} \sim 1.3\right)$; at the same time, when $\mathrm{ET}_{\mathrm{o}}$ is very high, because cloudiness is low, incoming solar radiation is at a yearly maximum and relative humidity is low. However, this is a highly avoided situation by irrigators, because of the high costs of energy in September and October.

The electric energy fares in most of Brazil are flagged (green, yellow, or red) according to the actual costs to produce energy in the country. In 2017, on an annual mean, $63.8 \%$ of the electricity generated was hydroelectric, $17.2 \%$ was produced from fossil fuels sources, other renewables (biomass, solar, and wind) accounted for $17.6 \%$, and nuclear participated with 1.3\% [27]. Hydroelectricity is usually much cheaper than the other sources, and its availability is also seasonal. So, during the end of the rainy season, when reservoirs are at the highest level, proportion of hydroelectricity increases and costs decrease (green flag), while at the end of the dry season (September and October), when reservoirs are at the lowest level, proportion of fossil fuels (and costs) increase, leading to the red flag tariff (Bandeira vermelha). Although this is the general pattern, other factors, like interannual variability of rainfall, and any other significant changes in supply or demand may also affect the flagging, which is updated monthly.

If the irrigators generally avoid having high consumption of water during the driest months, what management do they usually practice at this time of the year? The results of our interviews indicate that the most common situations are either to have a crop at the end of the cycle when $\mathrm{K}_{\mathrm{c}}$ is small $(\sim 0.65)$, or to have the crop cycle (and irrigation) finished by this time of the year. 
We then consider two scenarios of regional water management for these seven regions, an aggressive one and a conservative one. In the aggressive scenario, maximum crop output is emphasized; regionally, irrigators would be planting year-round crops (either perennial crops like coffee, or sequential seasonal crops, like soy, cotton, maize, or beans); if sequential seasonal crops, one of the crops would be at the end of the cycle in September and October $\left(K_{c}=0.65\right)$, demanding on average $5 \mathrm{~mm} /$ day $(150 \mathrm{~mm} / \mathrm{month})$ for all areas with irrigation systems installed; and irrigators plan to sow the next crop after the onset of rains in late October or November. The conservative scenario assumes that one-third of the irrigated area is cultivated with only two crops a year, and there is no irrigation during the driest months $\left(\mathrm{K}_{\mathrm{c}}=0\right)$; two-thirds of the irrigators still act aggressively, as in the previous scenario, some of them because they grow perennial crops and must irrigate year-round; all farmers still plan to sow the next crop after the onset of rains in late October or November, to minimize the costs of energy. Regional irrigation in this conservative scenario is the weighted average of the irrigation levels $(1 / 3 \times 0$ $+2 / 3 \times 150)$, or $100 \mathrm{~mm} /$ month.

Again, these are scenarios based on the declared experience of the local people. So far, there are no public yearbooks that document month-by-month variations in planted area, just snapshots of irrigated area that do not capture the quick growth of irrigation systems in the region, neither the seasonality, nor the timing of irrigated crops. In a future work, we plan to use remote sensing to estimate the actual amount of irrigated area and the irrigation period per center pivot as a function of time.

Water uptake for irrigation $\left(\mathrm{Q}_{\mathrm{I}}\right)$ was estimated from the multiplication of the total area irrigated by the water application rates in the two irrigation management scenarios. Evolution of $\mathrm{Q}_{\mathrm{I}}$ from 1990 to 2018 is shown in Figure 11, for regions R1 to R7. Discharge measurements are not available for these regions (except for R2, which will be analyzed again in Figure 12), so we use regionalized values of $Q_{90}$ [28]. This technique is a downscale of discharge for drainage areas smaller than the available measurements, using empirical equations based on independent variables like area upstream or average precipitation upstream. These authors tested several empirical relationships, and the best skill low streamflow regionalization was obtained by basin-specific regression equations of $\mathrm{Q}_{90}$ against the upstream long-term annual rainfall minus an initial abstraction of $750 \mathrm{~mm}\left(\mathrm{P}_{\text {eq750 }}=\mathrm{P}-750\right)$ as independent variable [29].

Figure 11 plots $80 \%$ of long-term $\mathrm{Q}_{90}$ (the maximum discharge that could be granted for all human use, including irrigation). A water use conflict situation appears when the demanded water resources (blue or green lines) are higher than the availability of water resources (horizontal dashed red line). The aggressive scenario (blue line) implies conflicts in regions R1, R2, and R4. In the Rio de Janeiro region (R2), at least since 1997, these conflicts may have been sporadically occurring, depending on year-by-year decision to irrigate in the low flow months. This helps explain why the installation of center pivots has been halted between 2005 and 2013 (Figure 10b). Conflicts, however, may be avoided by a community decision to follow the more conservative scenario, which tolerates additional increases in irrigation area, as observed after 2015 (Figure 10b).

In R3 and R5, although the estimated demand of water resources has not yet reached the limit of $80 \%$ LT Q90, they all show a quick increase in the use of water, and if the rates of irrigation growth continue to be high, water conflicts are imminent. In regions R6 and R7, although imminent conflicts may be in principle discarded, conflicts may still arise in the timescale of a decade or two, if irrigation growth rates remain high. 

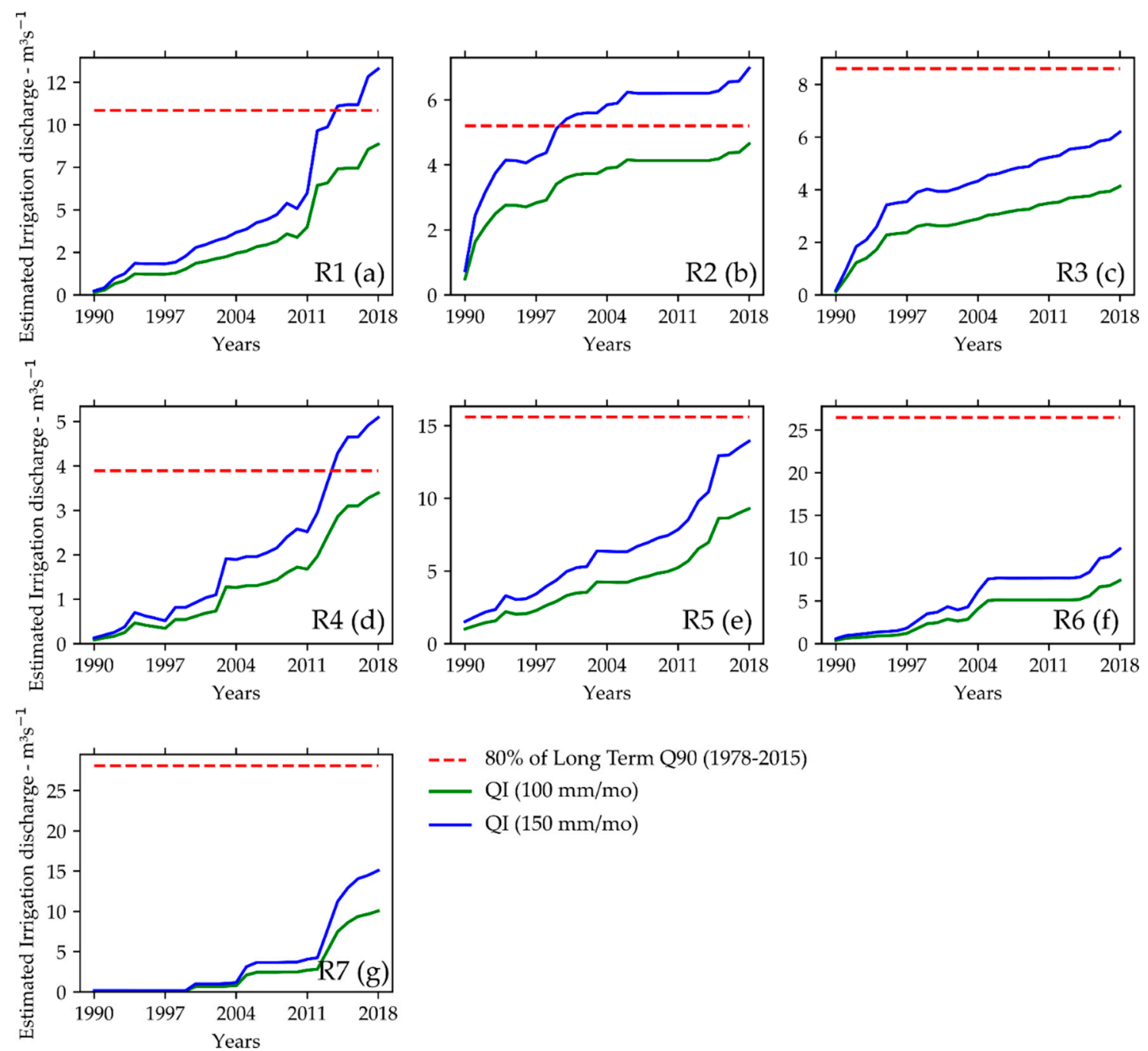

$--\quad 80 \%$ of Long Term Q90 (1978-2015)
- QI $(100 \mathrm{~mm} / \mathrm{mo})$
- QI $(150 \mathrm{~mm} / \mathrm{mo})$

Figure 11. Scenarios of discharge uptake for irrigation in selected regions, assuming two water application rates (100 and $150 \mathrm{~mm} / \mathrm{month}$ ). $80 \%$ of long-term $\mathrm{Q}_{90}$ is the maximum river discharge that can be granted permission for human use [17].

The intense growth of irrigation systems (90\% from 2010 to 2018, Table 2) is hardly the only concern for water users in Western Bahia. As described in Figure 7, the safe discharge for concession of water use permits, $\mathrm{Q}_{90}$, has decreased everywhere in the basin. $\mathrm{Q}_{90}$ is mostly defined by the discharges observed in P2 only, which covers the period 1993-2015, so the use of updated hydrological information is crucial to minimize the hydroclimatic risks (Figure 8). In fact, Figure 12A-F does a similar water conflict analysis for the six selected hydrological stations. Of those, four (Figure 12A-D) have much irrigation upstream, while two of them (Figure 12E,F) have little irrigation upstream. A remarkable feature of Figure 12 is the decrease of $\mathrm{Q}_{90}$, calculated only with data for P1 and only with data for P2 (black dashed lines). 

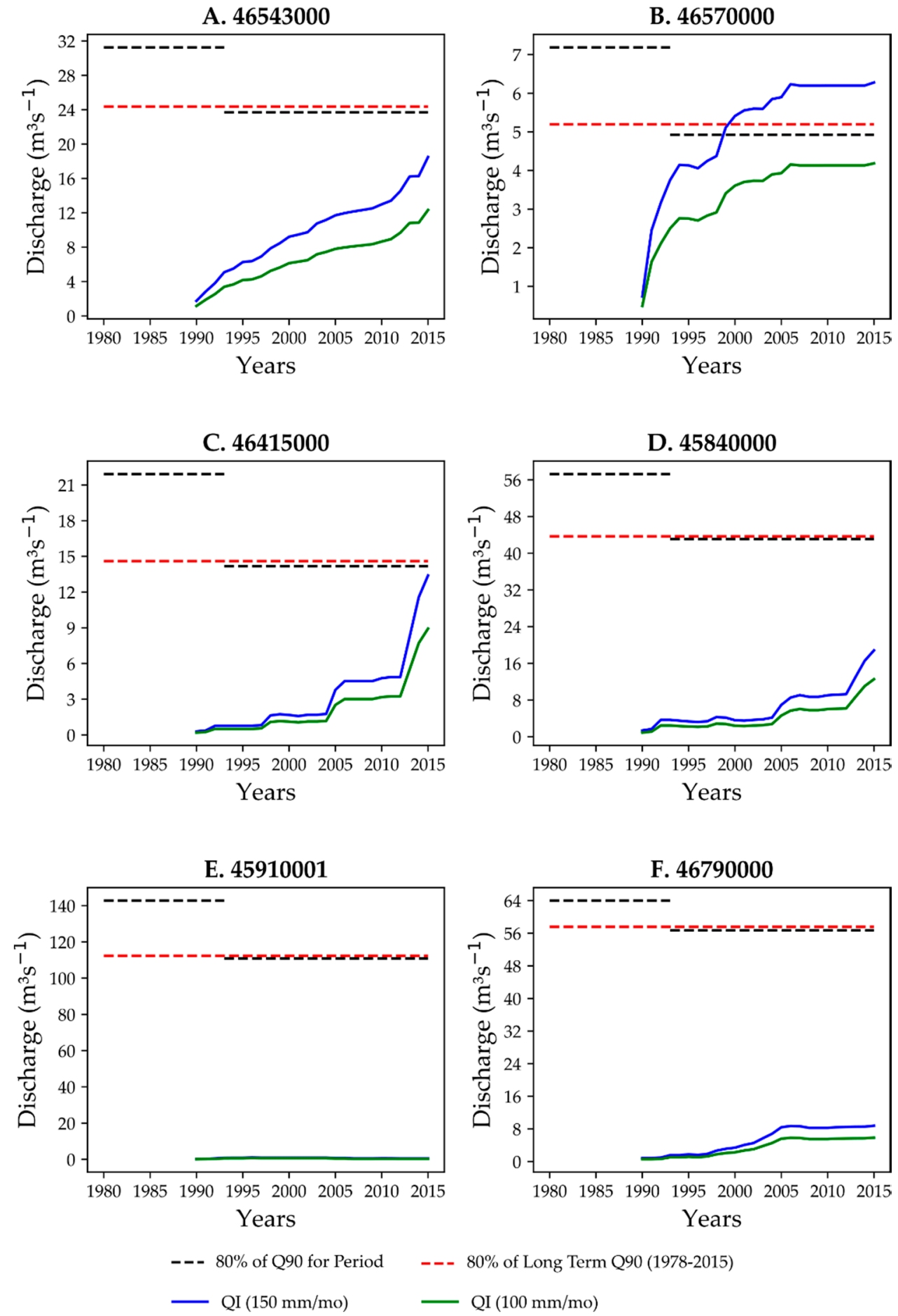

Figure 12. Evolution of discharge uptake for irrigation (QI) in the drainage area of each river flow station, assuming two water application rates (100 and $150 \mathrm{~mm} / \mathrm{month}) .80 \%$ of long-term $\mathrm{Q}_{90}$ (dashed red line) is the maximum that can be allocated at that point. The black dashed lines represent the change in the availability of water resources from P1 to P2.

\section{Discussion and Conclusions}

\subsection{Climate Change and Intense Iirrigation Growth: Increasing Water Stress}

An analysis of Figure 12A-D indicates that conflicts of water use may arise much sooner if outdated hydroclimatic information is used to define water granting rights. For example, a hypothetical $\mathrm{Q}_{90}$ 
defined using only pre-1992 data is between $15 \%$ and $60 \%$ higher than the $\mathrm{Q}_{90}$ calculated when the more recent years are considered (black dashed lines). Following the non-stationarity of the time series, the long-term $\mathrm{Q}_{90}(1978-2015)$ nearly coincides with the recent, shorter-term (P2) $\mathrm{Q}_{90}$ everywhere in the basin. In particular in Station B, which is coincident with R2, as early as the late 1990s, irrigation water demands, probably granted based on data of a wetter period, were no longer consistent with the decreasing availability of water resources. This inconsistency was probably understood in 2003, when discharge was low (below long-term $Q_{90}$ ) during $45 \%$ of the year (Figure $8 \mathrm{~b}$ ), leading to a halt in the installation of new center pivots in the area shortly after (Figure 10b). However, since 2015, irrigated area in the region has resumed its expansion, which is of much concern (Figure 10b). Water withdrawn for irrigation certainly affects the measurements, in particular in regions with a high density of irrigation systems like the sub-basin upstream of station B. This effect, however, is reduced in the other stations, which have a smaller density of irrigation systems.

At least seven sub-basins in Western Bahia are either in a state of conflict for the use of water or are moving rapidly towards it: Rio Branco, Rio de Janeiro, Rio Cabeceira de Pedras, Rio Borá, Rio de Ondas, Rio Grande (headwaters), and Rio Formoso. These sub-basins account for $17 \%$ of the area of Western Bahia. In these seven critical sub-basins, water conflicts are imminent, if irrigators actually irrigate in the driest months of the year, when discharge usually gets around or below $Q_{90}$. As a short-term alternative, conflicts can be avoided if irrigators largely avoid irrigation during these months. As shown in Figure 8, this is not restricted to a few months of the year. In many dry years, nearly half of the year daily discharges were below $Q_{90}$, with an extreme case in station $D$ (Formoso river) in the very dry year of 2015, when daily $Q$ was below $Q_{90}$ during $72 \%$ of the year. To be sure, such $\mathrm{Q}_{90}$ already includes 2015 data.

Because of the declining rains and water resources, the water resource concession limits ( $80 \%$ of LT $\mathrm{Q}_{90}$ ) may be reached with a much higher frequency than originally planned if outdated hydroclimate information is used. The combination of strong increase in demand of water for irrigation and the maintenance of low flows may bring much more critical consequences for water management in the region in the next years. Here, we discuss four different pathways to reduce water stress and increase water security: (i) Avoid irrigation during the low flow period; (ii) halt the installation of new irrigation systems; (iii) bet on a return to wet conditions; and (iv) invest in a hydroclimatic monitoring system.

\subsection{Avoid Irrigation during the Low Flow Period}

Avoiding irrigation during low-flow periods can be achieved by planting only two crops a year, one from November to February, and a second one from March to June. This is the most natural reaction to improve water security. This practice maximizes the use of rain during the six-month rainy season and cuts the use of irrigation to typically two months, reducing the water consumption not only because of the short irrigation period, but also because of the low ET rates at the end of the cycle. In addition to increasing water security, this practice also reduces production costs by avoiding the high costs of energy during the end of the dry season in Brazil, when additional energy tariffs (bandeira vermelha) are charged.

On the other hand, this practice has several drawbacks. Multiple cropping increases the revenue per plot, provides diversification of income, reduces pest pressure, and helps to maintain a more stable pool of farm labor, avoiding seasonal unemployment and the related social consequences [30]. It is also an important factor in the intensification of land use, which, if combined with additional conservation measures, reduces the pressure to expand cropland at the expense of natural ecosystems, possibly sparing land from deforestation. Moreover, this practice is not applicable on perennial crops.

\subsection{Halt the Installation of New Irrigation Systems}

Halting the installation of new irrigation systems, either through a ban of new water permits or by collective irrigators decision, is a short-term measure that vigorously attacks the problem from the 
viewpoint of the increasing demand. As stated earlier, this alternative has been requested by the Rio Corrente Basin Committee as a precautionary measure.

This option, however, does not resolve the conflicts of the regions already under a state of conflict, in particular in the Rio Grande basin, where the water demands are already too high in some places. It also does not address the problem of decreasing water availability. In addition, there are the economic consequences on jobs, tax revenue, and economic growth.

Although severe, it may be necessary in some regions with very high demands, in particular if the minimum discharges continue to decrease. A constant update of the low discharge values would be desired in this case.

\subsection{Bet on A Return to Wet Conditions}

The third alternative is to consider that current low precipitation period is not permanent and climate will return to the pre-1992 wet state.

Given the low skill of the current generation of interdecadal climate prediction models [31], it is hard to forecast whether these reducing precipitation trends will continue in the next decades. As said before, the location of Western Bahia in the transition between the semi-arid and the seasonally dry tropical climate regions makes it a serious candidate for climate change. CMIP5 simulations indicate a strengthening of the South Atlantic subtropical high, with a reduction of precipitation in the semi-arid of Northeast Brazil, and a possible expansion of the semi-arid climate over the region with a current seasonally dry climate [32]. This expansion, however, is somewhat uncertain given the relatively coarse resolution of the climate models involved in the CMIP5 ensemble (from $1.1^{\circ}$ to $2.8^{\circ}$ ), when compared to the east-west dimension of the region $\left(\sim 2.5^{\circ}\right)$. Despite the low skill of these models, the most likely scenario for the 21st century, as simulated by the CMIP5 ensemble, is an additional drying of the region, in particular in the months of September, October, and November, with very high agreement among models [21].

In addition, because the local rivers are connected to the Urucuia aquifer, pre-1992 river discharge levels may only be resumed after the aquifer previous levels of storage are restored, which may take from several years to several decades-our current understanding of the coupling of the aquifer and the rivers of the region is not sufficient to answer this question more precisely. Moreover, since the aquifer water level monitoring network was only set up in 2011, we do not know what the state of the aquifer was during the wet climate period.

In summary, climate models do not support a return to wet conditions-on the contrary. Even if climate models drying predictions do not materialize, it may take several decades to return to former conditions. Betting on this is a risky alternative.

\subsection{Invest in A Hydroclimatic Monitoring System}

The three alternatives discussed earlier may mitigate water conflicts, but all have their setbacks and risks. Western Bahia is an agriculture frontier under constant change, lacking a crucial element for management: Data. As stated earlier, the water resource management based on the long-term probability of hydroclimatic events requires at least a constant update of the low discharge values. But this does not seem to be sufficient. In the most water-stressed regions described above, a true management, in which the availability and demand of water resources for irrigation are actually measured and monitored, is the safest path to provide water security to this region. Such a monitoring system will allow a more confident and sustainable regional management of irrigated agriculture, maximizing the use of water resources, food production, and economic development, while reducing the risk of water conflicts.

This monitoring system should have three components: (1) Measurement and short term reporting of river discharge at key points in these basins, in particular in the sub-basins where the concentration of irrigation areas is higher; (2) a hydroclimatic forecast system to predict the availability of water resources at the period of lowest availability (September and October) several months in advance, 
in order to influence the irrigator decision to conduct an irrigated crop and when to plant this irrigated crop; and (3) monitoring and short-term reporting of the actual consumption of water for irrigation at the sub-basin scale. The latter can be done using either one of three possibilities: (i) Installation of hydrometers at each pumping station; (ii) correlation of water consumption with energy consumption, and monitor the latter; and (iii) monitor the actual evapotranspiration through operational remote sensing products, such as the MOD16 evapotranspiration product, correctly calibrated with field data for a reliable representation of reality. These measurements must be integrated at a monitoring center, which would periodically issue recommendations of how much area can be irrigated that year.

\subsection{Final Remarks}

It has been argued that water crises are mainly crises of governance [33]. Governance is a more inclusive concept than government itself, embracing the relationship between a society and its government. Governments mediate behavior through institutions, policies, laws, norms (like issuing water permits), and actions (like fiscalization and enforcement), but governance also relates to domestic activities, networks of influence, international market forces, the private sector, and civil society [34]. This concept has been incorporated by the Brazilian Policy on Water Resources (Law 9433 of 8 January 1997), which states that management of water resources must be decentralized with the participation of the government, users, and communities. The suggested monitoring system would provide the regional stakeholders (government agencies, agribusiness, and organized civil society) with the necessary data and decision-making tools to make key decisions.

One such key decision is the determination of how much area may be irrigated at each ottobasin in each year, a critical decision in this region with very high interannual variability of rainfall. The correct decision of how much area to be irrigated each year, according to the estimated availability of water resources, may contribute to avoid water use conflicts during the low water season, providing water security for both large irrigators and small farmers. If used wisely, it may also promote the long-term planning of the sustainable expansion of irrigation in the region, supporting the increase in the production of food, feed, and fiber, improving food security as well as water security.

Author Contributions: Conceptualization, methodology, project administration, and funding acquisition, M.H.C.; formal analysis, R.P.; writing-original draft preparation, review and editing, R.P. and M.H.C.; visualization, R.P. and F.M.P.; supporting data, V.C.F., V.F.A.d.B., and M.C.

Funding: This research was funded by PRODEAGRO (grant 011/2016) and CNPq (process 441210/2017-1). R.P. is supported through CAPES, Finance Code 001.

Conflicts of Interest: The authors declare no conflict of interest. The funders had no role in the design of the study, in the collection, analyses, or interpretation of data; in the writing of the manuscript, or in the decision to publish the results.

\section{References}

1. Yoffe, S.; Fiske, G.; Giordano, M.; Giordano, M.; Larson, K.; Stahl, K.; Wolf, T. Geography of international water conflict and cooperation: Data sets and applications. Water Resour. Res. 2004, 40, 1-12. [CrossRef]

2. Batistela, M.; Valladares, G.S. Farming expansion and land degradation in Western Bahia, Brazil. Biota Neotrop. 2009, 9, 61-76. [CrossRef]

3. AIBA (Associação de Agricultores e Irrigantes da Bahia). Anuário Agropecuário Oeste da Bahia-Safra 2015/2016. Available online: http://aiba.org.br/wp-content/uploads/2018/06/anuario-16-17.pdf (accessed on 15 July 2018).

4. ANA (Agência Nacional de Águas). Atlas de Irrigação-Uso da Água na Agricultura. 2017. Available online: http://arquivos.ana.gov.br/imprensa/publicacoes/AtlasIrrigacao-UsodaAguanaAgriculturaIrrigada. pdf (accessed on 17 December 2018).

5. ANA (Agência Nacional de Águas). Estudos hidrogeológicos na Bacia Hidrográfica do São FranciscoSistema Aquífero Urucuia/Areado e Sistema Aquífero Bambuí. Comitê Bacia Hidrográfica do São Francisco. 2013. Available online: http://cbhsaofrancisco.org.br (accessed on 11 November 2018). 
6. Web Map EPE—Sistema de Informações Geográficas do Setor Energético Brasileiro. Available online: https://gisepeprd.epe.gov.br/webmapepe/\# (accessed on 17 April 2019).

7. Ministério do Desenvolvimento, Indústria e Comércio Exterior. Panorama Agroeconomico do Oeste da Bahia e Safra 2016/17. Available online: http://www.mdic.gov.br/images/REPOSITORIO/czpe/Eventos/ZPE_ Agroneg\%C3\%B3cio/Panorama_do_agroneg\%C3\%B3cio_baiano_Aiba_Celestino_Zanella.pdf (accessed on 17 December 2018).

8. Almeida, W.A.; Moreira, M.C. Análise das outorgas da bacia do Rio Grande, Estado da Bahia. In Proceedings of the XLII Congresso Brasileiro de Engenharia Agrícola-CONBEA 2013, Campo Grande, Brazil, 27-31 July 2014.

9. Deliberação CBHRC 01/2015. Available online: https://www.conjur.com.br/dl/deliberacao-comite-baciacorrente.pdf (accessed on 17 April 2019).

10. G1. Grupo invade fazendas e incendeia galpão em protesto no Oeste da Bahia. Available online: https://g1.globo. com/bahia/noticia/grupo-invade-fazendas-e-incendeia-galpao-em-protesto-no-oeste-da-bahia.ghtml (accessed on 17 April 2019).

11. Correio 24 horas. Guerra pela água em Correntina se arrasta desde 2015. Available online: https: //www.correio24horas.com.br/noticia/nid/guerra-pela-agua-em-correntina-se-arrasta-desde-2015/ (accessed on 17 April 2019).

12. Xavier, A.C.; King, C.W.; Scanlon, B.R. Daily gridded meteorological variables in Brazil (1980-2013). Int. J. Climatol. 2016, 36, 2644-2659. [CrossRef]

13. Data Gridded Meteorological Data from 1980-2013 (and updated precipitation through 2015). Available online: http://careyking.com/data-downloads/ (accessed on 10 November 2018).

14. Pfafstetter, O. Classificação de Bacias Hidrográficas; Departamento Nacional de Obras de Saneamento: Rio de Janeiro, Brazil, 1989.

15. Verdin, K.L.; Verdin, J.P. A topological system for delineation and codification of the Earth's river basins. J. Hydrol. 1999, 218, 1-12. [CrossRef]

16. Pettitt, A.N. A non-parametric approach to the change-point problem. Appl. Stat. 1979, 2, 126-135. [CrossRef]

17. Verstraeten, G.; Poesen, J.; Demarée, G.; Salles, C. Long-term (105 years) variability in rain erosivity as derived from 10-min rainfall depth data for Ukkel (Brussels, Belgium): Implications for assessing soil erosion rates. J. Geophys. Res. 2006, 111, 1-11. [CrossRef]

18. Rybski, D.; Bunde, A.; Havlin, S.; von Stoch, H. Long-term persistence in climate and the detection problem. Geophys. Res. Lett. 2006, 33, 1-4. [CrossRef]

19. Mitchell, J.M., Jr.; Dzerdzeevskii, B.; Flohn, H.; Hofmeyr, W.L.; Lamb, H.H.; Rao, K.N.; Wallén, C.C. Climatic Change; WMO Technical Note No. 79; World Meteorological Organization: Geneva, Switzerland, 1966.

20. Landau, E.C.; Guimarães, D.P.; Souza, D.L. Concentração de áreas irrigadas por pivôs no Oeste da Bahia. In Proceedings of the Anais do Simpósio Regional de Geoprocessamento e Sensoriamento Remoto-GEONORDESTE 2014, Aracajú, Brazil, 18-21 November 2014.

21. Marengo, J.A.; Torres, R.R.; Alves, L.M. Drought in Northeast Brazil—Past, Present, and Future. Theor. Appl. Climatol. 2017, 129, 1189-1200. [CrossRef]

22. Kane, R.P. Prediction of Droughts in North-East Brazil: Role of ENSO and Use of Periodicities. Int. J. Climatol. 1997, 17, 655-665. [CrossRef]

23. Ambrizzi, T.; Souza, E.B.; Pulwarty, R.S. The Hadley and Walker Regional Circulations and Associated ENSO Impacts on the South American Seasonal Rainfall. In The Hadley Circulation: Present, Past and Future; Diaz, H.F., Bradley, R.S., Eds.; Kluwer Academic: Dordrecht, The Netherlands, 2004; Volume 21, pp. 203-235.

24. Marques, E.A.G.; Silva Júnior, G.C.; Illambwetsi, A.M.; Eger, G.Z.S.; Pousa, R.; Generoso, T.N.; Oliveira, J. Analysis of Groundwater Table and River Stage Fluctuations and their Relation to Rainfall and Water Use on Alto Grande Watershed, Northeastern Brazil. Unpublished work. 2018.

25. Bayazit, M. Nonstationary of hydrological records and recent trends in trend analysis: A state-of-the-art review. Environ. Process. 2015, 2, 247-542.

26. Serinaldi, F.; Kilsby, C.G. Stationarity is undead: Uncertainty dominates the distribution of extremes. Adv. Water Res. 2005, 77, 17-36. [CrossRef]

27. Ministério de Minas e Energia. Empresa de Pesquisa Energética, Brazilian Energy Balance. Available online: http://epe.gov.br/en/publications/publications/brazilian-energy-balance (accessed on 17 April 2019). 
28. Oliveira, J.R.S.; Ribeiro, R.B.; Sousa, J.R.C.; Serrano, L.O.; Ramos, M.C.A.R.; Generoso, T.N.; Pruski, F.F. Hydrological Information System to quantify water availability (SIHBA). Unpublished work. 2019.

29. Pruski, F.F.; Rodriguez, R.D.G.; Nunes, A.A.; Pruski, P.L.; Singh, V.P. Low-flow estimates in regions of extrapolation of the regionalization equations: A new concept. Eng. Agríc. 2015, 35, 808-816. [CrossRef]

30. Richards, P.; Pellegrina, H.; VanWey, L.; Spera, S. Soybean development: The impact of a decade of agricultural change on urban and economic growth in Mato Grosso, Brazil. PLoS ONE 2015, 10, e0122510. [CrossRef] [PubMed]

31. Kirtman, B.; Power, S.B.; Adedoyin, J.A.; Boer, G.J.; Bojariu, R.; Camilloni, I.; Doblas-Reyes, F.J.; Fiore, A.M.; Kimoto, M.; Meehl, G.A.; et al. Near-term Climate Change: Projections and Predictability. In Climate Change 2013: The Physical Science Basis. Contribution of Working Group I to the Fifth Assessment Report of the Intergovernmental Panel on Climate Change; Stocker, T.F., Qin, D., Plattner, G.-K., Tignor, M., Allen, S.K., Boschung, J., Nauels, A., Xia, Y., Bex, V., Midgley, P.M., Eds.; Cambridge University Press: Cambridge, UK; New York, NY, USA, 2013; pp. 953-1028.

32. Magrin, G.O.; Marengo, J.A.; Boulanger, J.-P.; Buckeridge, M.S.; Castellanos, E.; Poveda, G.; Scarano, F.R.; Vicuña, S. Central and South America. In Climate Change 2014: Impacts, Adaptation, and Vulnerability. Part B: Regional Aspects. Contribution of Working Group II to the Fifth Assessment Report of the Intergovernmental Panel on Climate Change; Barros, V.R., Field, C.B., Dokken, D.J., Mastrandrea, M.D., Mach, K.J., Bilir, T.E., Chatterjee, M., Ebi, K.L., Estrada, Y.O., Genova, R.C., et al., Eds.; Cambridge University Press: Cambridge, UK; New York, NY, USA, 2014; pp. 1499-1566.

33. United Nations Educational, Scientific and Cultural Organization (UNESCO); World Water Assessment Programme. Water, a Shared Responsibility; The United Nations World Water Report 2; Berghahn Books: Paris, France; New York, NY, USA, 2006; pp. 43-86.

34. Rogers, P.; Hall, A.W. Effective Water Governance; Global Water Partnership Technical Committee Background Papers No. 7; Global Water Partnership: Stockholm, Sweden, 2003.

(C) 2019 by the authors. Licensee MDPI, Basel, Switzerland. This article is an open access article distributed under the terms and conditions of the Creative Commons Attribution (CC BY) license (http://creativecommons.org/licenses/by/4.0/). 